
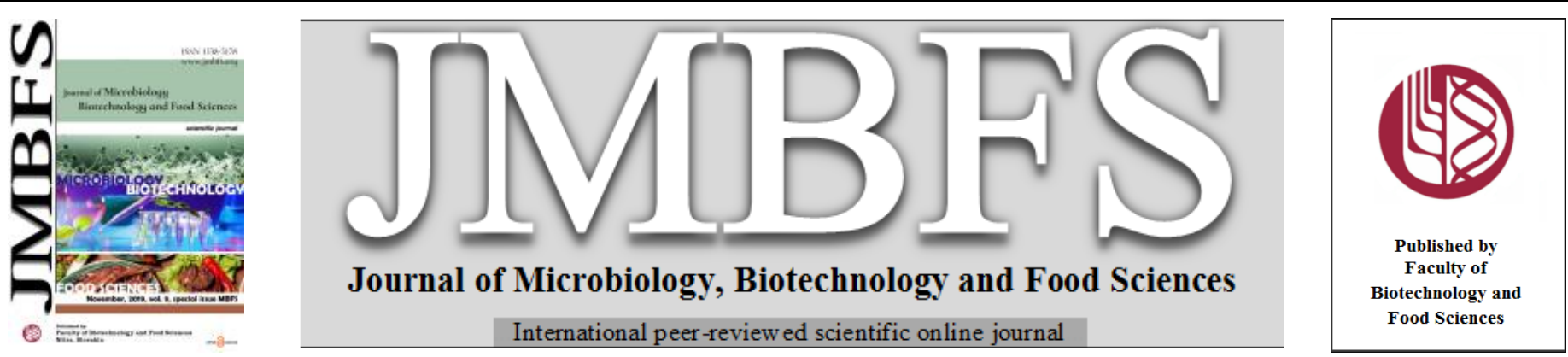

\title{
INFLUENCE OF STARTER CULTURE TO SENSORY QUALITY OF EDAM CHEESE DURING RIPENING
}

\author{
Šustová Květoslava* ${ }^{1}$, Kráčmar Stanislav ${ }^{1,2}$, Fišera Miroslav ${ }^{1,3}$, Burešová Pavlal \\ Address(es): \\ ${ }^{1}$ College of Business and Hotel Management Brno, Bosonožská 9, 62500 Brno, Czech Republic, +420 547218247. \\ ${ }^{2}$ Thomas Bata University in Zlín, Faculty of Technology, Department of Food Technology, Vavrečkova 275, 76001 Zlín, Czech Republic. \\ ${ }^{3}$ Thomas Bata University in Zlín, Faculty of Technology, Department of Food Analysis and Chemistry, Vavrečkova 275, 76001 Zlín, Czech Republic.
}

*Corresponding author: sustova@ hotskolabrno.cz

doi: 10.15414/jmbfs.2019.9.special.422-426

\section{ARTICLE INFO}

Received 25. 7. 2019

Revised 18. 9. 2019

Accepted 2. 10. 2019

Published 8. 11. 2019

Regular article

open $\partial_{\text {ACCESS }}$

\begin{abstract}
In the study were evaluated the Edam cheeses with fat content $30 \%$ and $45 \% \mathrm{w} / \mathrm{w}$ produced by two dairies (A, B) using two different starter cultures YY and LL during five months ripening. The effect of ripening was related to the texture of Edam, so as to determine the optimum ripening time. The ripening time had significant effect on sensory characteristics of the Edam cheese. The first three months were ripening cheese with $30 \%$ fat in dry matter evaluated much like cheese with $45 \%$ fat in dry matter, but in the following months of aging is already evident that with the starter culture LL cheeses were evaluated as taste pleasant. Both starter cultures produced an increase in the bitter taste of the cheeses after 3 months of ripening. However, cheeses with YY starter culture gradually lost bitterness during ripening, while for cheeses with LL starter culture the intensity of the bitter taste increased during ripening. These results were statistically significant. Increasing bitter taste formation excludes the possibility of using YY starter culture to make Edam cheese with a maturation period of more than 3 months.
\end{abstract}

Keywords: maturation, hardness between fingers, hardness in the mouth, bitter taste

\section{INTRODUCTION}

Edam cheeses rank among natural semi-hard cheeses with low-heated curds Edam cheeses have a delicate, not too salty taste and a very delicate pleasant aroma. Edam color is slightly yellow to light yellow; pale cheese is an indicator of insufficient speed and ripening time (Roginski et al., 2003). The main characteristics of sensory analysis of semi-hard and hard cheeses are appearance, texture and flavor (taste, smell and aroma). According to the International Dairy Federation standard, the following characteristics are assessed in the order specified: external appearance - shape, wrapping or rind and surface of whole surface of cheese; internal appearance - pinholing and color, visual evaluation of section or drill sample; consistency / texture - evaluation of samples by bending, squeezing between forefinger and thumb, and chewing; flavor - evaluation is performed by smelling and chewing the sample (Spreer, 1998). Bérodier $\boldsymbol{e t}$ al. (1997) states that the characteristics of cheeses are evaluated in the following order: smell, aroma, essential flavors, irritating (aggressive) flavors, subsequent flavors and flavor persistence. The basic (primary) taste is any of the distinctive flavors, including acidic, bitter, salty, alkaline, umami and metallic (ČSN ISO 5492). As irritating flavors can be evaluated as the following: burning, prickly (nettle), astringent, bitter, refreshing, metal and the like. Texture plays an evaluation very important role because they can mask or reduce defects in taste, flavor and aroma (Bodyfelt et al., 1988; Lavanchy et al., 1994; Němcová et al., 2013).

Edam type cheeses must be matured for at least 40 days to fully develop the desired sensory traits (Bertola et al., 2000). Important is slow ripening, which shows better results than fast ripening. In the Netherlands, which is the place of origin of edammer (Edam), cheese is considered to be well after four months of maturation (Callec, 2003). The disadvantage of longer ripening is the increasing price of cheese. On the other hand, cheeses acquire stronger sensory properties and their texture is better accepted by consumers, knowledgeable consumers prefer medium to much mature cheeses for a more pronounced, more complex flavor and more acceptable texture, as confirmed by a study conducted by Yates and Drake (2007).

In the production of Edam cheese used dairy starter cultures added to pasteurized milk before renneting. These are mostly mixed cultures of microorganisms whose individual microbial species stimulate each other. The function of starter culture consists mainly of lactic acid production, proteolytic and lipolytic action of microbial enzymes, formation of sensory active substances and antimicrobial action. It is therefore clear that the starter culture used contribute to the organoleptic characteristics of the cheeses, the intensity of which depends on the extent and depth of ripening (Smit et al., 2005). All young cheeses (with some exceptions) have a similar composition in terms of protein, fat and milk sugar Only the microbial and enzymatic fermentation of these components of young cheeses produces substances which give the cheeses their typical properties, appearance, smell, taste and texture (McSweeney and Sousa, 2000; McSweeney, 2004; Kayagil, 2006; Pachlová et al., 2009). During ripening edam cheese may arise some defects flavour are mostly bitter taste, which is caused by a higher concentration of bitter peptides arising inter alia in cheese proteolytic activity of microbial enzymes. These peptides may further be degraded to shorter peptides or amino acids that are not bitter (McSweeney, 2004; McSweeney et al., 2006). The intensity of proteolysis depends on many factors, notably the maturation time (Sousa et al., 2001).

Many authorial works, such as Yates and Drake (2007), have been evaluating sensory changes resulting from the maturation of Edam cheese (Bertola, 2000; Foegeding et al., 2003; Buchar et al., 2013).

Gonzales-Vias et al. (2001) report that there are correlations between the mechanical and sensory properties of cheeses. Kücüköner and Haque (2003) compared the different rheological properties of Edam with a fat content of 30\% and $45 \%$ dry matter at 6 months of age. The results of the measurements show that after four months of maturation the cheeses acquire a softer structure, which was correlated with the increase in cheese proteolysis products. Similar results were reported by Němcová $\boldsymbol{e t ~ a l . ~ ( 2 0 1 3 ) . ~}$

During ripening, the structure of Edam cheeses becomes more homogeneous and more elastic as the curd grain diffuses in the cheese mass. The $\mathrm{pH}$ of cheeses slightly increases thanks to the enzyme activity, the operation of which causes alkalic compounds to release. In the course of cheese ripening, bitter peptides may form (Visser et al., 1983; Haque and Antila, 1993). The hydrophobic amino acids contained in the peptides are the main factor of growing bitterness of the cheeses (Mulholland, 1992). Jameson, (1990), Olson and Johnson (1990) and Drake et al. (1995) found out that fat is an important carrier of the texture and taste. Jensen (1998), Lynch et al. (1999) that it is important to follow the taste and texture mainly in Edam cheeses with decreased fat content.

The authors Tungjaroenchai $\boldsymbol{e t}$ al. (2001) followed the development of taste and texture in Edam cheeses with decreased fat content, using different starte cultures. They found out that no differences have manifested in the course of ripening. After the 4th month, they recorded an influence of the used culture on 
the textural properties of the cheeses. The effect of the ripening temperature on proteolysis and on organoleptic properties of Edam cheeses was followed by Kujawski et al. (2003).

Also Jasińska et al. (2007) compared the changes in selected sensoric attributes in Edam cheeses with fat contents in dry matter of $28 \%$ and $50 \%$ for the ripening period of 6 weeks. The cheeses with a higher fat content have shown a more intensive colour, finer consistence and latterly also a better taste than cheeses with low fat content in dry matter. Kubiš et al. (2013) dealt with a sensorics evaluation of the texture of Edam cheeses ripening from 1 to 25 weeks. Mainly in case of Edam with $45 \%$ of fat in dry matter, elasticity and compressibility of the sample has been increasing in the course of ripening.

Edam cheeses are usually matured for 4 to 12 weeks (Roginski et al., 2003). In the Czech Republic, they are usually produced from shorter maturation times. If the ripening period of the cheeses is prolonged, taste defects may occur in the cheeses, due to the poor microbial quality of the milk but also due to the incorrectly used pure milk culture.

The aim of the work was:

1. evaluation of sensory changes of Edam cheeses during 5 months of maturation,

2. comparison of sensory changes during maturation of Edam cheeses with different fat content,

3. verification of the influence of two different starter cultures on the resulting sensory quality of Edam cheese.

\section{MATERIAL AND METHODS}

\section{Material}

Edam cheeses with a $30 \%$ and $45 \%$ fat content in dry matter, produced with the same milk in two dairies (A, B), have been evaluated, using two different types of starter cultures (LL, YY). The surface and central parts of cheeses have been evaluated separately during five month of ripening.

Starter cultures LL: Lactococcus lactis ssp. lactis a Lactococcus lactis ssp. cremoris.

Starter cultures YY: Lactococcus lactis subsp. cremoris, Lactococcus lactis subsp. lactis, Leuconostoc mesenteroides subsp. cremoris, Lactococcus lactis subsp. diacetylactis, Streptococcus thermophilus a Lactobacillus helveticus.

\section{Methods}

\section{Sensory analysis}

The sensory analysis of the cheeses has been conducted by a ten-member expert commission. The sensoric laboratory satisfied requirements of the ĆSN EN ISO 8589 standard. A graphic non-structured scale with $100 \mathrm{~mm}$ length with a verbal description of the end points has been used for evaluation. Before the evaluation, cheeses were left for 2 hours at room temperature $\left(20 \pm 2{ }^{\circ} \mathrm{C}\right)$, with the aim to facilitate the required development of taste and smell. As the textural properties for evaluation were chosen the following - hardness in the mouth (Lavanchy $\boldsymbol{e}$ al., 1994) and hardness between fingers according to Hort $\boldsymbol{e t}$ al. (1997). An examination of the overall taste, bitter taste intensity as well as appearance of the cheeses have also been included.

\section{Statistical analysis}

The results of analyses have been evaluated with Unistat 4.53 and Microsoft Excel 2000 software. The differences between monitored parameters were tested with the Tukey's HSD test (Dufek, 1992).

\section{RESULTS AND DISCUSSION}

Samples of Edam cheese made from the same milk in two dairy technology establishments taken each month and sensory analysed by a 10-member expert committee. The sensory profiles of the followed Edam cheeses during five month of ripening are shown in graphic charts 1 to 9 . The appearance of cheeses was better evaluated after a longer ripening period then in the beginning. In onemonth ripe cheeses, the non-homogeneous appearance of cheeses was evaluated negatively, as well as the noticeable salt ring and the grains visibly glued together. After a longer ripening period, an increase of cracks, hollows and sometimes also nutty holes in cheeses have been recorded. When evaluating the overall appearance of cheeses, a difference between the used cultures has been found, which is evident from the Figure 1 and 2.
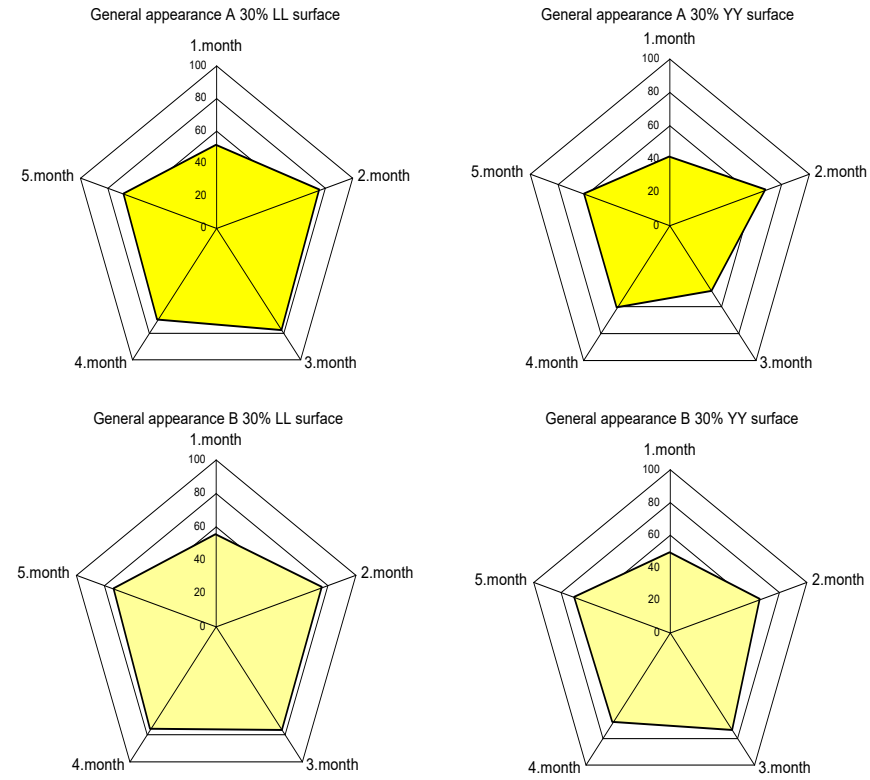

Figure 1 Results of sensory evaluation of appearance comfort during 5 months of maturation in Edam cheese with 30\% TVS using YY and LL cultures
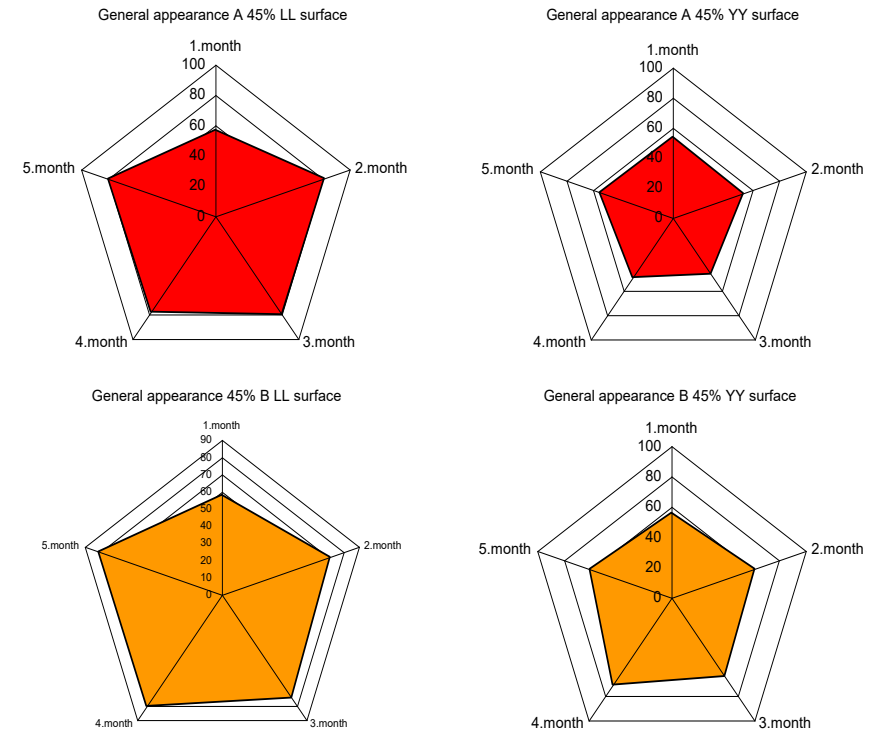

Figure 2 Results of sensory evaluation of appearance comfort during 5 months of maturation for Edam cheese with 45\% TVS using YY and LL cultures.

In cheeses produced by using the LL culture starter, taste as well as appearance was evaluated as better. The occurrence of cracks is, according Kněz and Sedláčková (1991), a typical shortcoming of hard cheeses, caused by no observance of required temperatures, acidity and time of curing the cheeses with salt. Olšanský and Kněz (1971) state that the cheeses with a lower $\mathrm{pH}$ are more acid in taste, less elastic and creating cracks in the course of ripening. Yo et al. (2018) observed an increase in the aroma, flavor and aroma during ripening of Gouda cheese too.

The hardness between fingers has been detected at the beginning of the ripening period of Edam cheeses as significantly higher on the surface of the cheeses than in the centre. Since beginning of the ripening of cheeses, hardness in case of both fat contents and in case of both used starter cultures has been decreasing gradually. The samples of Edam cheeses with $30 \%$ fat content in dry matter had a Edams with 45\% FDM. A higher fat content in cheeses causes higher viscosity and a softer consistence. Cheeses with a lower fat content are harder and more rubberlike. Our results correlate with the work of Drake et al. (1995).

When evaluating hardness of cheeses between fingers, differences between hardness on the surface and in the centre of the cheeses were recorded. At the beginning of ripening (1st month), there is a significantly higher hardness on surface layer of the cheese in samples of cheeses with 30\% FDM from the dairy works B compared to the dairy works $\mathrm{A}$ and this is the case in both cultures (Figures 3 and 4). 

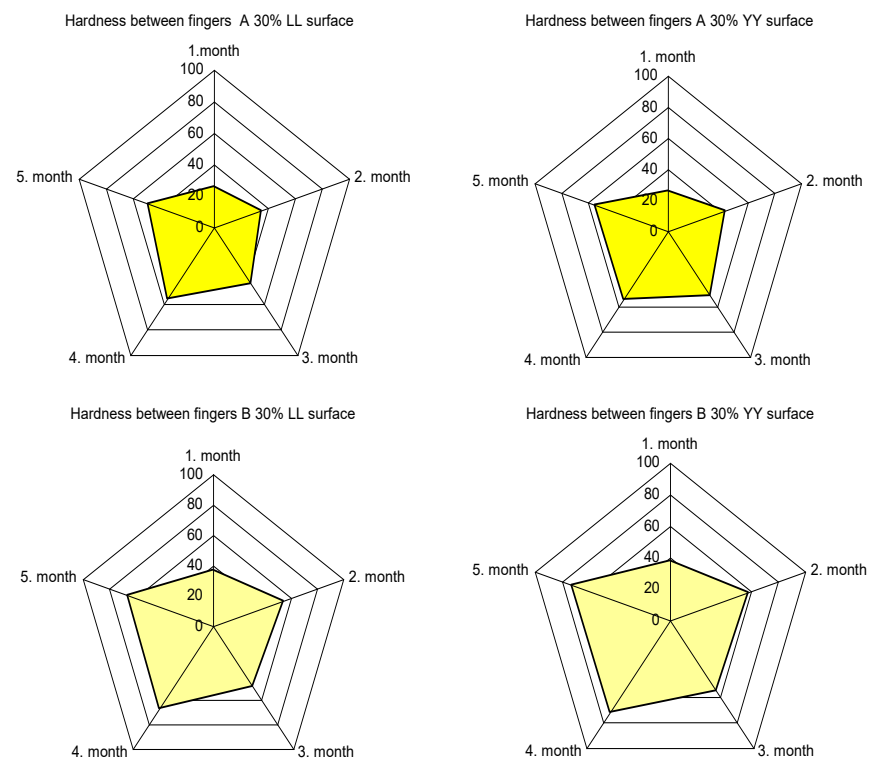

Figure 3 Results of sensory evaluation of finger hardness during 5 months of maturation in Edam cheese with 30\% TVS using YY and LL cultures.
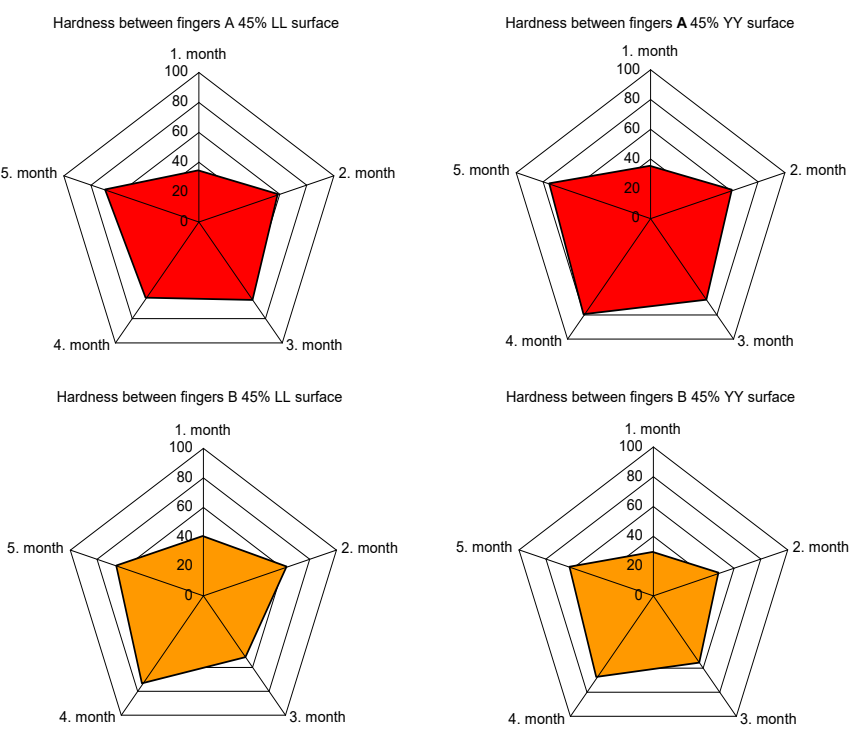

Figure 4 Results of sensory evaluation of finger hardness during 5 months of maturation in Edam cheese with 45\% TVS using YY and LL cultures.

This difference has evened out after 2 months of ripening. After a month of ripening, a statistically significant highly conclusive difference has been recorded in hardness between the surface and centre of cheeses of both dairy works and in both fat contents. No more statistic differences in hardness between the surface and centre of the Edam cheeses have been found in further months. Similar results are confirmed by the research works Kubiš et al. (2013).

Hardness in the mouth had a similar course as the hardness between fingers. In the course of ripening of the cheeses, it also gradually came to a continuous decrease in hardness in the mouth. A minimal hardness in the mouth has been established in the third month of ripening, while later on, hardness has slightly been decreasing again. Since the second month of ripening, not even differences in hardness in the mouth have been established in cheeses from the dairy works B owing to different fat content. Sadowska et al. (2009) and Vítová et al. (2011) also confirms the change in cheese hardness during ripening. In sensorics profiles of Edam cheeses, there is a marked difference in hardness in the mouth between the used cultures. Cheeses produces with the LL starter culture have been evaluated as harder in the course of ripening (see Figure 5 and 6).
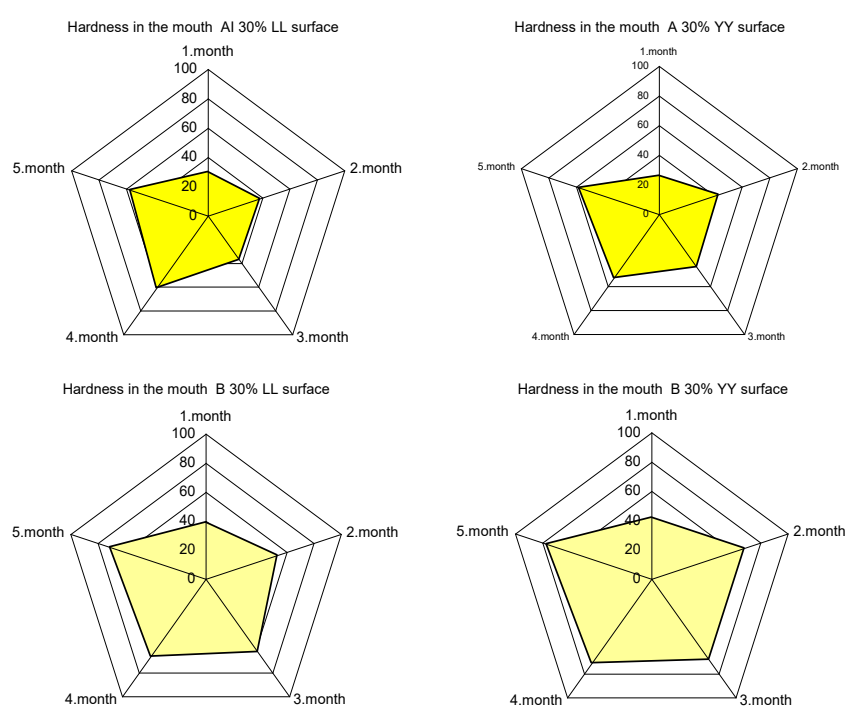

Figure 5 Results of sensory evaluation of mouth hardness during 5 months of maturation in Edam cheese with 30\% TVS using YY and LL cultures.
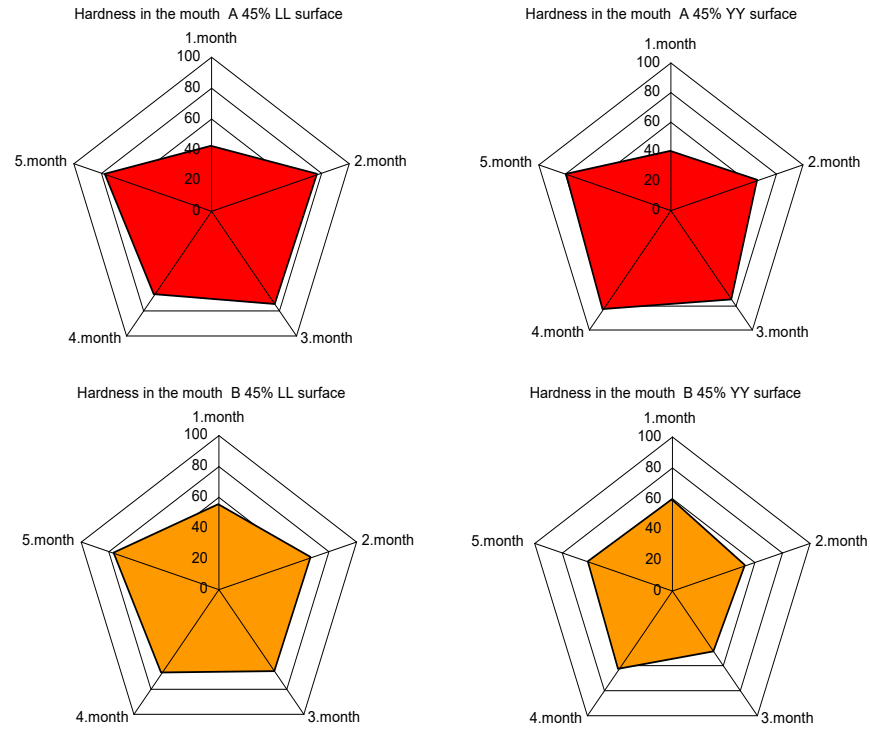

Figure 6 Results of sensory evaluation of mouth hardness during 5 months maturation in Edam cheese with 45\% TVS using YY and LL cultures.

The overall palatability of the taste of cheeses was at their lowest in the beginning of ripening, when the taste of young cheeses has not yet fully developed, and later, when the taste of the cheeses has been evaluated negatively at the end of ripening. In taste of the cheeses, the intensity of bitter taste started to significantly increase after three months of ripening. Because showing the difference in the development of bitter taste in cheeses with culture using the LL and YY, the bitter taste were organoleptically evaluated even after 6 months of ripening. The bitter taste of Edam cheese during ripening was the same as for cheeses with $30 \%$ fat in dry matter and for cheeses with $45 \%$ fat in dry matter. Mainly in case of cheeses produced by using the YY starter culture, the development of taste in the course of ripening of the cheeses has been evaluated negatively, in both types of fat content as well as in both dairy works (Figures 7 to 9 ).

The influence of used starter cultures on cheese quality was statistically confirmed in the taste parameters of cheeses, especially in bitter taste formation during ripening. Proteolytic enzymes of some Lactococcus strains are characterized by a significant production of bitter peptides (Visser $\boldsymbol{e t}$ al., 1983; Görner and Valík, 2000). The bitter taste can also be caused by some amino acids, amides, acids and ketones with long chains emergent during ripening (McSweeney and Sousa, 2000). In cheeses with using the YY starter culture, the creation of bitter peptides was obviously faster because of larger counts of the used bacteria strains. Lemieux and Simard (1991) state that the bitter taste produced during maturation is due, among other things, to the proteolytic activity of dairy bacteria. This is also indicated by our results, when the influence of different cultures was manifested. 

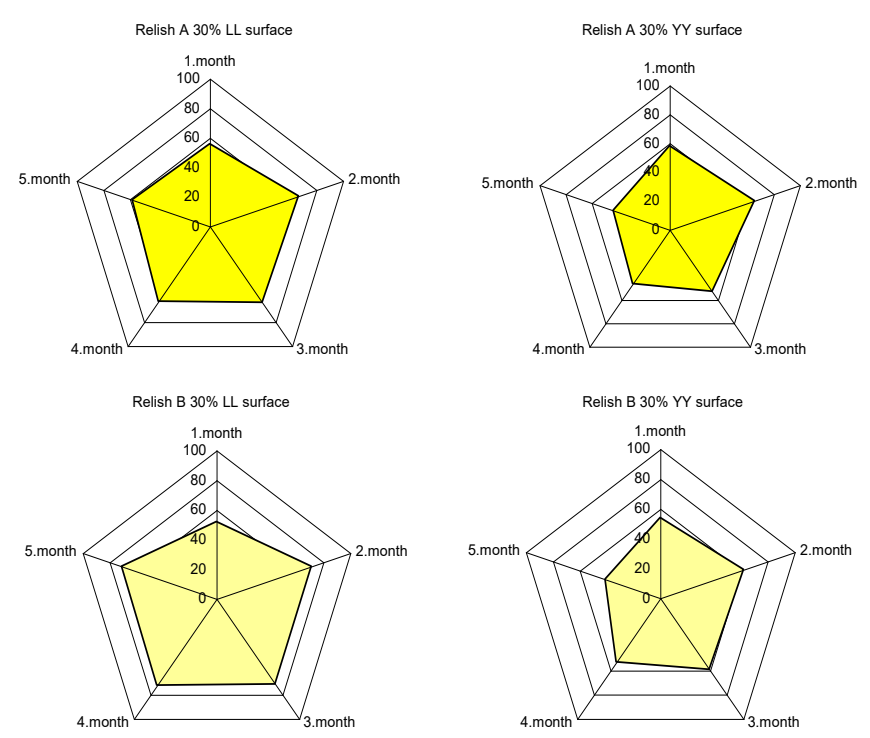

Figure 7 Results of sensory evaluation of the taste comfort during 5 months of maturation in Edam cheese with 30\% TVS using YY and LL cultures.
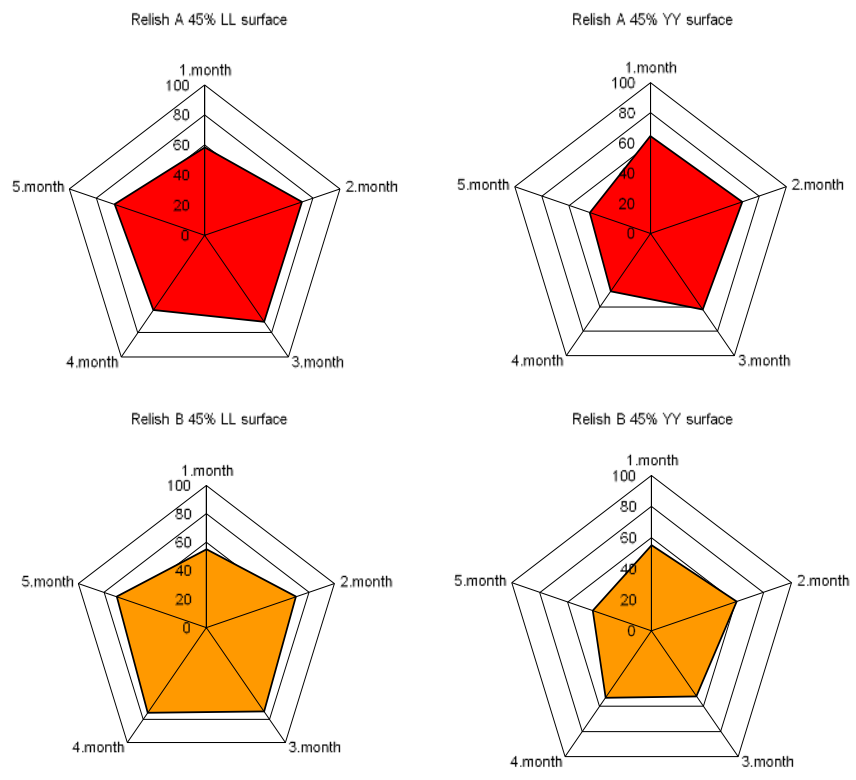

Figure 8 Results of sensory evaluation of flavor pleasure during 5 months of maturation in Edam cheese with 45\% TVS using YY and LL cultures.

The results of the work show that the starter culture used has a great influence not only on the texture properties of Edam cheeses, but also on the pleasant taste of the cheeses and their appearance. Both starter cultures negatively influenced the bitter cheeses during ripening. Greater influence on the formation of bitter peptides had a starter culture of YY, which is probably due to the larger proportion of bacteria of the genus Lactococcus. Sensory analysis shows that this starter culture is not suitable for cheese production with a maturation period of more than 3 months.

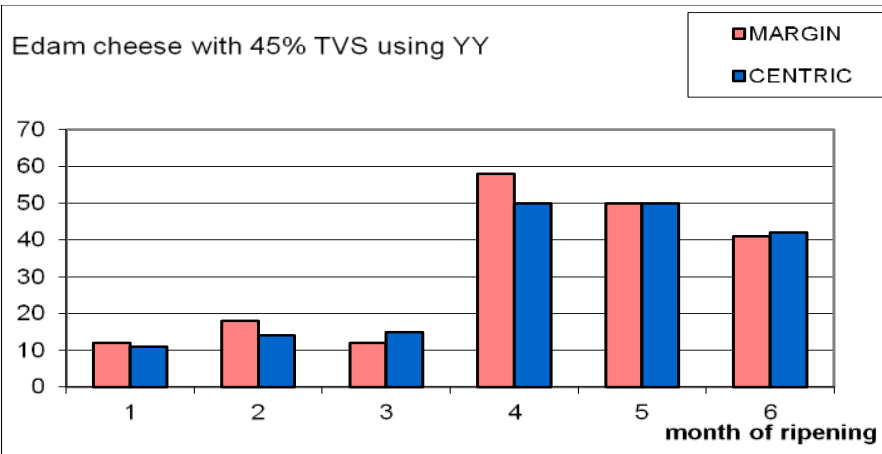

Edam cheese with $45 \%$ TVS using LL

口MARGIN 口CENTRIC

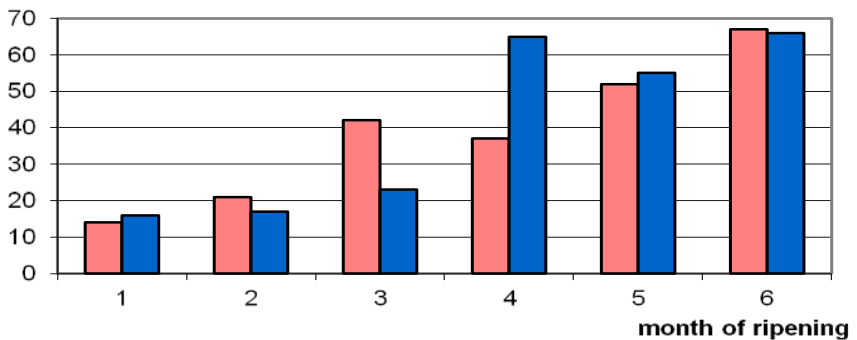

Figure 9 Intensity of bitter taste during 6 month of ripening for Edam cheese using YY and LL cultures.

\section{CONCLUSION}

Edam type cheeses with $30 \%$ and $45 \%$ fat in dry matter, produced by two dairy works (A, B) using two different starter cultures (YY, LL) in the course of five months of ripening have been evaluated in the study. Impact of the ripening upon the Edam sensory quality for the determination of the optimal ripening time has been evaluated. Better outcomes in evaluations have been recorded sensorically in cheeses ripening for three months with higher fat content in dry matter. Statistically highly conclusive differences have been found in the taste of cheeses produced by using different cultures. Mainly in cheeses produced with the use of YY culture, the development of the bitter taste in the course of ripening of cheeses has been negatively evaluated. The cheeses produced with the use of LL culture were evaluated with better outcome what concerns their appearance as well as their taste.

Generally, the results confirmed that the period of ripening had a significant impact upon the rheologic properties of the Edam cheeses. The texture improvement was related to the increasing time of ripening. From the beginning of the ripening of cheeses, the hardness between fingers has gradually been decreasing in both fat contents as well as in both used starter cultures. The hardness has been found to be significantly higher in the surface layer than in the center of the cheese at the beginning of ripening of the Edam cheeses. The results of evaluation of hardness in the mouth recorded a similar course as the hardness between fingers. In the course of ripening of cheeses, a gradual decrease of hardness in the mouth has been recorded as well. 45\% FDM cheese was evaluated as softer, more smearness and more palatable. Hardness in mouth and hardness between fingers decreased, cohesiveness and smearness increased. $45 \%$ FDM cheese was evaluated as softer, more smearness and more palatable.

In the sensoric evaluation of cheeses, no statistically conclusive influence of the used culture on textural properties in the course of ripening has been found Cheese had better value up to the third month of ripening. If the period of maturation was extended up to six months, there were undesirable flavours, first the bitter taste and strange flavour. Cheeses with YY starter culture gradually lost bitterness during ripening, while for cheeses with LL starter culture the intensity of the bitter taste increased during ripening. These results were statistically significant. Increasing bitter taste formation excludes the possibility of using YY starter culture to make Edam cheese with a maturation period of more than 3 months.

Acknowledgments: The research this article reports on was implemented under the support of the operational Program called Research and Development for Innovations that is co-funded by the European Fund for Regional Development (ERDF) and also subsidized from the state budget of the Czech Republic within the Centre of Polymer Systems Project (reg. n.: CZ.1.05/2.1.00/03.0111) and 2112 - Institutional Support for the Development of Research Organizations.

\section{REFERENCES}

BÉRODIER, F., LAVANCHY, P., ZANNONI, M., CASALS, J., HERRERO, L., $\mathrm{ADAMO}, \mathrm{C}$. A guide to thesensory avaluation of smell, aroma and taste of hard 
and semihard cheeses. Lebensmittel-Wissenschaft \& Technology, 1997, 30, 653664. ISSN 1096-1127.

BERTOLA, N.C., CALIFANO, A.N., BEVILACQUA, A.E., ZARITZKY, N.E. Effects of ripening conditions on the texture of Gouda cheese. Journal of Food Science and Technology [online]. 2000, 35(2), 207-214 [cit. 2019-09-03]. DOI: 10.1046/j.1365-2621.2000.00347.x.

BODYFELT, F.W., TOBIAS, J., TROUT, G. M. The sensory evaluation of dairy products. AVI Book, 1988, $247 \mathrm{p}$

BUCHAR, J., KUBIŠ, I. , GAJDƯŠEK, S., KŘIVÁNEK, I. Influence of cheese ripening on the viscoelastic behaviour of edam cheese. Czech Journal of Food Sciences [online]. 2013, 19(No. 1), 1-7 [cit. 2019-09-04]. DOI: 10.17221/6566CJFS

CALLEC, CH. Encyklopedie sýrü. Translated MARTÍNKOVÁ, P. Čestlice: Rebo Productions, 2002. ISBN 80-7234-225-8

ČSN ISO 5492 (56 0030) Senzorická analýza - Slovnik. The Czech version of the International Standard ISO 5492:1992.

ČSN EN ISO 8589 (56 0036) Senzorická analýza - Obecné pokyny pro uspořádáni senzorického pracoviště. Sonsory analysis - general guidance for the desingn of test rooms.

DRAKE, M.A., HERFETT, W., BOYLSTON, T.D., SWANSON, B.G. Sensory Evaluation of Reduced Fat Cheeses. Journal of Food Science [online]. 1995, 60(5), 898-901 [cit. 2019-09-03]. DOI: 10.1111/j.1365-2621.1995.tb06256.x.

DUFEK, J. Biometrika. VŠZ v Brně, 1992, 152 p. ISBN 80-7157-0287-3.

FOEGEDING,.A.E., BROWN, J., DRAKE, M.A., DAUBERT, CH.R. Sensory and mechanical aspects of cheese texture. International Dairy Journal [online]. 2003, 13(8), 585-591 [cit. 2019-09-03]. DOI: 10.1016/S0958-6946(03)00094-3. GONZÁLEZ-VIÑAS, M.A., JUSTA POVEDA, J., ANTONIA GARCÍA RUIZ, A.G., LOURDES CABEZAS, L. Changes in chemical sensory and rheological characteristics of manchego cheeses during ripening. Journal of Sensory Studies [online]. 2001, 16(4), 361-371 [cit. 2019-09-03]. DOI: 10.1111/j.1745459X.2001.tb00307.x.

GÖRNER, F., VALíK, L. Aplikovaná mikrobiológia poživatín: princípy mikrobiológie poživatín, potravinársky významné mikroorganizmy a ich skupiny, mikrobiológia potravinárskych výrob, ochorenia mikrobiálneho pôvodu, ktorých zárodky sú prenášané poživatinami. Bratislava: Malé Centrum, 2004, $528 \mathrm{~s}$. ISBN 80-967064-9-7.

HAQUE, Z.U., ANTILA, P. Milk peptides: effect on the enzymatic hydrolysis of sodium caseinate. Agriculture Science In Finland, 1993, F 2: 371- 377. ISSN 0789-600X

HORT, J., GRYS, G., WOODMAN, J. The relationships between the chemical, rheological and textural properties of Cheddar cheese. Le Lait, INRA Editions, 1997, 77 (5), pp.587-600. HAL Id: hal-00929549

JAMESON, G., W. Cheese with less fat. Australian Journal of Dairy Technology, 1990, 45, 93-98. ISSN 0004-9433.

JASINSKA, M., DMYTROW, I., STRADOMSKI, A. Changes of selected quality attributes of Edam cheese with various fat contents during storage. Polish Journal of Food and Nutrition Sciences [online] 57 (1): 31-38. [cit. 2010-04-21]. Dostupný z WWW: <journal.pan.olsztyn.pl/fd.php?f=821>.

JENSEN, K.N. Use of cultures in reduced-fat Jarlsberg-typecheese. M. S. Thesis Mississippi State University. Mississippi, 1998.

JO, Y., BENOIST, D.M., AMEERALLY, A., DRAKE, M.A. Sensory and chemical properties of Gouda cheese. Journal of Dairy Science [online]. 2018 101(3), 1967-1989 [cit. 2019-09-03]. DOI: 10.3168/jds.2017-13637.

KAYAGIL, F. Effect of Traditional Starter Cultures on Quality of Cheese. In Partial Fulfillment of the Requirements for the Degree of the Master of Science in Biotechnology, Middel East Technical University. Ankara, Turkey, 2006, 75 p KNĚZ, V., SEDLÁČKOVÁ, H. Sýry a př́prava sýrových jídel. 1991, 4. vyd. Praha: SNTL, 196 s.

KÜÇÜKÖNER, E., HAQUE, Z. U. Physico-chemical and Rheologica Properties of Full Fat and Low Fat Edam Cheeses, European Food Research Technology, 2003, 217: 281 - 286. ISSN 1438-2385.

KUBIŠ, I., KŘIVÁNEK, I., GAJDU゚ŠEK, S. The relationships between the chemical, dielectric and sensory properties of Edam cheese during ripening. Czech Journal of Food Sciences [online]. 2013, 19(No. 3), 85-89 [cit. 2019-0904]. DOI: $10.17221 / 6582-C J F S$.

KUJAWSKI, M., CICHOZS, G., PODHAJNA, E., SANKO, B. Effect of ripening on proteolysis and organoleptic properities of Edam-type cheese, Electornic Journal of Polish Agricultural Universities, Food Science and Technology, 2003, 6, 1-9. ISSN 1505-0297.

LAVANCHY, P., BÉRODIER, F., ZANNONI, M., NOEL, Y., ADAMO, C., SQUELLA, J., HERRERO, L. Guide to the sensory evaluation of texture of hard and semi-hard cheeses. INRA, 1994, $40 \mathrm{p}$.

LEMIEUX, L., SIMARD, R.E. Bitter flavour in dairy products. A review of the factors likely to influence its development, mainly in cheese manufacture. Review article. Lait, 1991, 71, 599-636. ISSN 0023-7302.

LYNCH, C.M., MUIR, D.D., BANKS, J.M., MCSWEENEY, P.L.H., FOX, P.F. Influence of Adjunct Cultures of Lactobacillus paracasei ssp. paracasei or Lactobacillus plantarum on Cheddar Cheese Ripening. Journal of Dairy Science [online]. 1999, 82(8), 1618-1628 [cit. 2019-09-03]. DOI: 10.3168/jds.S00220302(99)75390-7.
McSWEENEY, P. L. H., HAYALOGLU, A. A., O'MAHONY, J. A ., BANSAL, N. Perspectives on cheese ripening. Australian Journal of Dairy Technology, 2006, 61, 2: 69-77. ISSN 0004-9433.

McSWEENEY, P.L.H. Biochemistry of cheese ripening. International Journal of Dairy Technology [online]. 2004, 57(2-3), 127-144 [cit. 2019-09-03]. DOI: 10.1111/j.1471-0307.2004.00147.x.

McSWEENEY, P.L.H., SOUSA, M.J. Biochemical pathways for the production of flavour compounds in cheeses during ripening: A review. Le Lait [online]. 2000, 80(3), 293-324 [cit. 2019-09-03]. DOI: 10.1051/lait:2000127. ISSN 0023 7302 .

MULHOLLAND, F. Flavor peptides: the potential role of Lactococcal peptidases in their production. Food Biotechnology, 1992, 19, 685-690. ISSN 0890-5436.

NĚMCOVÁ, I., ŠTĚTINA, J., VALENTOVÁ, H. Proteolysis and consistency changes of Gouda and Eidamský blok cheeses during ripening. Czech Journal of Food Sciences [online]. 2013, 19(No. 2), 67-72 [cit. 2019-09-03]. DOI: 10.17221/6578-CJFS.

OLSON, N., F., JOHNSON, M., E. Light cheese products: characteristics and economics. Food Technology, 1990, 44(10), 93. ISSN 0015-6639.

OLŠANSKÝ, Č., KNĚZ, V. Výroba tvrdých sýri eidamského a ementálského typu, ČAZ-VÚPP, Praha, 1971, $289 \mathrm{p}$

PACHLOVÁ, V., BUŇKA, F., BUŇKOVÁ, L., WEISEROVÁ, E., HLADKÁ, K., VOJTÍŠKKOVÁ, P., KRÁČMAR, S. Vliv průběhu zrání na obsah vybraných složek v př́rodním sýru eidamského typu. Potravinárstvo, 2009, 3, 1:33-36. ISSN 1337-0960.

ROGINSKI, H.,. FUQUAY, J.W., FOX, P. F. Encyclopedia of dairy sciences. New York: Academic Press, c2003. ISBN 0-12-227235-8.

SADOWSKA, J., BIAŁOBRZEWSKI, I., JELIŃSKI, T., MARKOWSKI, M. Effect of fat content and storage time on the rheological properties of Dutch-type cheese. Journal of Food Engineering [online]. 2009, 94(3-4), 254-259 [cit. 201909-03]. DOI: 10.1016/j.jfoodeng.2009.03.015.

SMIT, G., SMIT, B.A., ENGELS, W.J.M. Flavour formation by lactic acid bacteria and biochemical flavour profiling of cheese products. FEMS Microbiology Reviews [online]. 2005, 29(3), 591-610 [cit. 2019-09-03]. DOI 10.1016/j.fmrre.2005.04.002.

SOUSA, M.J, ARDÖ, Y., McSWEENEY, P.L.H. Advances in the study of proteolysis during cheese ripening. International Dairy Journal [online]. 2001, 11(4-7), 327-345 [cit. 2019-09-03]. DOI: 10.1016/S0958-6946(01)00062-0.

SPREER, E., MIXA, A. Milk and dairy product technology. New York: M. Dekker, c1998. Food science and technology (Marcel Dekker, Inc.), 84. ISBN 08247-0094-5.

TUNGJAROENCHAI, W., DRAKE, M.A., WHITE, C.H. Influence of Adjunct Cultures on Ripening of Reduced Fat Edam Cheeses. Journal of Dairy Science [online]. 2001, 84(10), 2117-2124 [cit. 2019-09-03]. DOI: 10.3168/jds.S00220302(01)74656-5.

YATES, M.D. a M.A. DRAKE. Texture properties of gouda chesse. Journal of Sensory Studies [online]. 2007, 22(5), 493-506 [cit. 2019-09-03]. DOI: 10.1111/j.1745-459X.2007.00124.x. ISSN 0887-8250. Dostupné Z: http://doi.wiley.com/10.1111/j.1745-459X.2007.00124.x

VISSER, S., SLANGEN, K.J., HUP, G., STADHOUDERS, J. Bitter flavour in cheese. 3. Comparative gelchromatographic analysis of hydrophobic peptide fractions from 12 gouda type cheeses and identification of bitter peptides isolated from a cheese made with streptoccocus-cremoris strain hp. Nethelands Milk and Dairy Journal, 1983, 37 (3), 181-192. ISSN 0028-209X.

VÍTOVÁ, E., MOKÁNOVÁ, R., BABÁK, L., ZEMANOVÁ, J., SKLENÁŘOVÁ, $\mathrm{K}$. The changes of flavour and aroma active compounds content during production of Edam cheese. Acta Universitatis Agriculturae et Silviculturae Mendelianae Brunensis [online]. 2011, 59(1), 255-262 [cit. 201909-03]. DOI: 10.11118/actaun201159010255. 